\title{
CASE COMMENT: SCOTT v. BIRDSELL LIMITATION PERIODS IN MEDICAL MALPRACTICE CASES
}

\author{
GERALD B. ROBERTSON*
}

Section 55 of Alberta's Limitation of Actions Act ${ }^{1}$ provides that an action for negligence or malpractice against certain health care professionals (including physicians and dentists) must be commenced "within one year from the date when the professional services terminated in respect of the matter that is the subject of the complaint." The recent decision of Mr. Justice Hutchinson in Scott v. Birdsell is the first Alberta case to have addressed the important issue of whether section 55 is subject to the common law "discoverability" rule. ${ }^{3}$

In Canada the discoverability rule has its origins in the 1984 Supreme Court of Canada decision in City of Kamloops v. Nielsen. ${ }^{4}$ Writing for the majority, Madam Justice Wilson held that a cause of action for negligence does not accrue (and hence the limitation period does not start to run) until the plaintiff discovers or ought to have discovered the injury. In its later decision in Central Trust Co. v. Rafuse $e^{5}$ the Supreme Court of Canada expanded this by holding that the cause of action does not accrue until the plaintiff discovers or ought to have discovered the material facts on which the cause of action is based. ${ }^{6}$ Further expansion can be seen in the Supreme Court's recent decision in $M .(K$.$) v. M .(H .)^{7}$ (a tort action based on child sexual abuse and incest), in which the Court stated that a cause of action does not arise until the plaintiff is reasonably capable of discovering the wrongful nature of the defendant's acts and the nexus between those acts and her injuries. ${ }^{8}$

In Scott v. Birdsell the plaintiff brought an action for alleged negligence against the physician who had performed breast reconstruction surgery on her. The action was commenced more than one year after the operation, and so the plaintiff advanced a number of arguments in an effort to overcome the limitation problem facing her. One of these was that section 55 is subject to the discoverability rule enunciated by the Supreme

Professor of Law, University of Alberta.

R.S.A. 1980, c. L-15.

(1993), 143 A.R. 254 (Q.B.).

In Freeman v. Lavoie (1989), 95 A.R. 66 (Q.B.), Mr. Justice Deyell commented (at 67) that the discoverability rule does not apply to section 55, but this comment was obiter and made without detailed analysis.

[1984] 2 S.C.R. 2.

[1986] 2 S.C.R. 147.

For a detailed discussion of the discoverability rule see R.W. Bauman, "The Discoverability Principle:

A Time Bomb in Alberta Limitations Law" (1993) 1 Health L.J. 65; W.H. Hurlburt, "Hill v. Registrar: Limitation of Actions, the Assurance Fund and the 'Discoverability' Rule" (1993) 31 Alta.

L. Rev. 692.

$7 \quad$ [1992] 3 S.C.R. 6.

$8 \quad$ See also Murphy v. Welsh; Stoddard v. Watson, [1993] 2 S.C.R. 1069. 
Court of Canada and hence the limitation period in her case did not start to run until she discovered the material facts on which the cause of action was based. ${ }^{9}$

Mr. Justice Hutchinson rejected this submission and held that section 55 is not subject to a discoverability rule. In arriving at this conclusion he relied extensively on Fehr v. $J a c o b,{ }^{10}$ in which the Manitoba Court of Appeal held that section 61 of that province's Medical Act ${ }^{11}$ (which is similar, though not identical, to Alberta's section 55) is not subject to the common law discoverability rule. The reasoning in Fehr v. Jacob, which was expressly adopted in Scott v. Birdsell, is simple. The effect of the discoverability rule, according to the Supreme Court of Canada, is to postpone the accrual of the cause of action until the material facts are discovered. Where, as in the present case, the commencement of the limitation period is not linked to the accrual of the cause of action but rather is tied to another specified date (such as the termination of professional services), the discoverability rule does not apply. ${ }^{12}$ In the words of Justice Twaddle in Fehr,${ }^{13}$ which were quoted by Justice Hutchinson in Scott: ${ }^{14}$

In my opinion, the judge-made discoverability rule is nothing more than a rule of construction. Whenever a statute requires an action to be commenced within a specified time from the happening of a specific event, the statutory language must be construed. When time runs from the "accrual of the cause of action" or from some other event which can be construed as occurring only when the injured party has knowledge of the injury sustained, the judge-made discoverability rule applies. But, when time runs from an event which clearly occurs without regard to the injured party's knowledge, the judge-made discoverability rule may not extend the period the legislature has prescribed.

It is regrettable that Mr. Justice Hutchinson chose to rely so heavily on the Manitoba Court of Appeal's decision in Fehr v. Jacob, almost to the exclusion of any other legal reasoning or analysis. His discussion of this highly significant issue occupied only about two pages of judgment, most of which was taken up with quotations from Fehr v. Jacob and $M .(K$.$) v. M$.(H.). ${ }^{15}$ There is no mention of the Saskatchewan Court of Appeal's decision in Desormeau v. Holy Family Hospital, Prince Albert, ${ }^{16}$ which applied the

Other arguments included that professional services did not terminate after the operation, because of a subsequent appointment which the plaintiff alleged she had made with the defendant; that the professional services did not terminate, because the treatment remained incomplete; and that at the material time she was "under disability" within section 59 of the Act. None of these arguments was successful. [1993] 5 W.W.R. 1 (Man. C.A.). See also J.(A.) v. Cairnie Estate, [1993] 6 W.W.R. 305 (Man. C.A.).

R.S.M. 1987, c. M90 (also C.C.S.M., c. M90).

This is a view which I previously endorsed: see G.B. Robertson, "Fraudulent Concealment and the Duty to Disclose Medical Mistakes" (1987) 25 Alta. L. Rev. 215 at 219-220. It will be apparent that I have since changed my mind. Supra note 10 at 6-7.

14 Supra note 2 at 265 . Note, however, that according to this reasoning the discoverability rule does apply to section $\mathbf{5 6}$ of the Alberta legislation, which provides that an action against a hospital must be commenced within one year after the cause of action arose. 
discoverability rule to analogous legislation ${ }^{17}$ and which was distinguished on very tenuous grounds in Fehr v. Jacob. Moreover, closer examination of the Manitoba legislation reveals that reliance on Fehr v. Jacob is misplaced. As the Manitoba Court of Appeal itself noted, that province's legislation contains a discoverability rule which provides that a plaintiff who is otherwise time-barred may apply to the court within one year of discovering the material facts, and the court has a discretion to allow the action to proceed. ${ }^{18}$ This provision tends to support the interpretation adopted in Fehr v. Jacob, since if the Manitoba legislature has chosen to provide an express discoverability rule in this way it is reasonable to assume that it did not intend that the rule should be implied in other sections. The Manitoba provision also mitigates the harshness of the decision in Fehr v. Jacob. This is very different from the situation facing the Court in Scott v. Birdsell.

The most striking feature of Scott v. Birdsell is the patent injustice of the decision "the injustice of a law which statute-bars a claim before the plaintiff is even aware of its existence". ${ }^{19}$ Indeed, the injustice (and absurdity) are even greater than this, since the reasoning in Scott v. Birdsell means that the limitation period in section 55 will expire even if the injury has not yet occurred and hence before the cause of action has even arisen. ${ }^{20}$ The decision in Scott invites the question posed by one American judge: ${ }^{21}$

How can anyone be precluded from asserting a claim by a statute of limitations which expires before the discovery of the injury? How can anyone charged with the responsibility of administering justice allow such an absurdity?

One response to this, of course, is that responsibility for remedying the injustice lies with the legislature rather than with the courts. However, this overlooks the fact that the Supreme Court of Canada has already assumed this responsibility by introducing a discoverability rule into the common law. In choosing not to apply this rule to section 55, Scott v. Birdsell takes far too narrow an interpretation of the Supreme Court decisions. While it is true that the discoverability rule is enunciated in these decisions in terms of postponing the accrual of the cause of action, this is merely a convenient mechanism for achieving the policy objective which the Supreme Court was ultimately seeking to achieve, namely, the postponement of the limitation period where the plaintiff is unaware of the material facts. To view the Supreme Court decisions as applying only where the limitation period is tied to the accrual of the cause of action places too literal a construction on these decisions, and completely ignores their underlying policy

The Hospital Standards Act, R.S.S. 1978, c. H-10, s. 15, provides, inter alia, that no action shall be brought against a hospital "after the expiration of three months from the date on which the damages are sustained". The Court held that this section was subject to a discoverability rule, even though the limitation period was not linked to the accrual of the cause of action.

Limitation of Actions Act, R.S.M. 1987, c. L150 (also C.C.S.M., c. L150), s. 14(1).

City of Kamloops v. Nielsen, supra note 4, per Wilson, J. at 40.

A situation which one American judge described as declaring "the bread stale before it is baked" Fleishman v. Eli Lilly \& Co., 465 N.Y.S. 2d 735 (1983), per Gibbons, J. at 737, quoted in Prosser \& Keeton on the Law of Torts, 5th ed. 1988 Supplement at 25.

Amer v. Akron City Hospital, 351 N.E. $2 d 479$ (Ohio, 1979), per Celebrezze, C.J. at 485. 
justification. Nor do there appear to be any cogent policy grounds which would warrant this narrow interpretation.

While the Alberta Court of Appeal has indicated an unwillingness to expand the discoverability rule, ${ }^{22}$ hopefully the Court will take the opportunity, when it arises, to remedy the injustice and absurdity arising from Scott v. Birdsell. 